\title{
Effects of folic acid administration on testicular ischemia/ reperfusion injury in rats ${ }^{1}$
}

\begin{abstract}
Aris Fakouri', Ahmad Asghari", Ghasem Akbari"', Pejman Mortazavi"v
'Graduate student, Science and Research Branch, Islamic Azad University, Tehran, Iran. Technical procedures, acquisition and interpretation of data.

"Associate Professor, Department of Surgery, Science and Research Branch, Islamic Azad University, Tehran, Iran. Design and supervised all phases of the study, manuscript writing.

"'Assistant Professor, Department of Theriogenology, Science and Research Branch, Islamic Azad University, Tehran, Iran. Design of the study, analysis and interpretation of data.

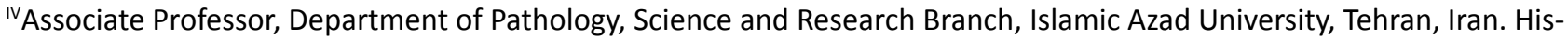
tological examinations.
\end{abstract}

\section{Abstract}

Purpose: To determine the effect of folic acid (FA) on experimental testicular ischemia/reperfusion (I/R) in rats.

Methods: Sixty male Wistar rats were randomly divided into 6 groups. The control group received physiologic saline orally. The sham-operated group received physiologic saline orally then exposed to midline laparotomy without clamping the IR. The I/R rats received oral gavage of the saline then subjected to $1 \mathrm{~h}$ ischemia $/ 24 \mathrm{~h}$ reperfusion, period. In folic acid ( $2 \mathrm{mg} /$ $\mathrm{kg}+\mathrm{IR})$ rats received oral gavage of the FA $(2 \mathrm{mg} / \mathrm{kg})$ then subjected to $1 \mathrm{~h} \mathrm{I} / 24 \mathrm{~h} \mathrm{R}$. groups 5-6 received FA (5 and $10 \mathrm{mg} / \mathrm{kg}$ ), then subjected to $1 \mathrm{~h} \mathrm{I} / 24 \mathrm{~h}$, respectively. At the end of the study, semen samples were collected for spermatozoa characteristics. The left testis was removed for histological analysis and superoxide dismutase (SOD), malondialdehyde (MDA) and glutathione peroxidase (GPx) measurement.

Results: Spermatozoa mobility, mortality (\%) significantly decreased in I/R group $(P<0.05)$. Dose dependent increase observed on spermatozoa mobility, mortality (\%) using different levels of the FA $(2,5$ and $10 \mathrm{mg} / \mathrm{kg})$ treated rat $(P<0.05)$. Tissue MDA levels significantly increased in $\mathrm{I} / \mathrm{R}$ rat $(P<0.05)$ while FA $(2,5$ and $10 \mathrm{mg} / \mathrm{kg})$ in a dose dependent manner decreased I/R-induced MDA ( $P<0.05)$. Experimental I/R significantly decreased SOD and GPx activity $(P<0.05)$. Administration of the $F A(2,5$ and $10 \mathrm{mg} / \mathrm{kg})$ significantly increased tissue SOD and GPx activity in I/R rat $(P<0.05)$. Seminiferous tubules degenerated and loss of spermatogenesis with few spermatocytes was observed in degenerated testis tubules in I/R rat. Orally administration of the FA ( 5 and $10 \mathrm{mg} / \mathrm{kg}$ ) improved testis characteristics with few normal seminiferous tubules and spermatocyte in seminiferous tubules in experimental I/Rinduced rat.

Conclusion: The treatment of folic acid had a benefit effect against ischemia-reperfusion. Key words: Folic Acid. Ischemia. Reperfusion. Rats. 


\section{Introduction}

Testiculartorsion is a urologicemergency that occurs frequently in the neonatal and adolescent period. The testicular torsion characterized by a circulatory failure caused via testis revolving around the vascular peduncle ${ }^{1}$. Annual incidence of spermatic cord torsion is 4.5 in 100.000 males $1-25$ years of age ${ }^{2,3}$. The main pathophysiologic event in testicular torsion is ischemia followed by reperfusion; therefore, testicular torsionedetorsion is an ischemia/reperfusion $(I / R)$ injury to the testis ${ }^{4}$. In the $I / R$, blood supply of the tissue is interrupted which leads to damage of metabolically active tissues and cellular and tissue damage eventually ${ }^{5}$. The basic pathology in testicular torsion is ischemia which happens because of the torsion followed by tissue damage occurring via the reactive oxygen species (ROS) during reperfusion ${ }^{6}$. Excess production of ROS or decreased antioxidant defences in the seminal plasma ${ }^{7}$. Activation of several antioxidant defense mechanisms avoids the tissue damage due to ROS ${ }^{8}$. The ROS antioxidants such as SOD, MDA and GPx have an essential effect in human reproduction. Polyunsaturated fatty acids (PUAFAs) are highly concentrated in spermatozoa and vulnerable to be attacked by $\operatorname{ROS}^{9}$. To date several antiinflammatory, antioxidants, and free-radical scavengers were applied for the treatment of testicular I/R-induced male infertility ${ }^{9}$.

Folic acid/ folate (FA), is a water-soluble vitamin. FA is essential for the production of purines and pyrimidines which as precursors of $D_{N A}{ }^{10}$. FA modulates a number of disorders as a result of its antiapoptotic and anti-oxidative properties $^{11}$. It is reported FA $(2 \mathrm{mg} / \mathrm{kg})$ has gastroprotective activity against the lipid peroxidation $^{11}$. It is reported FA, the synthetic form of folate has effective antioxidant activity in male infertility ${ }^{7}$. Also, curative effect of the FA observed on sperm parameters and
DNA integrity following varicocelectomy ${ }^{13}$. Despite free radical scavenging property of the FA is approved ${ }^{14}$, scarce information exists for its antioxidant activity. Researches were done on antioxidant activity of the FA in liver and digestive system; there is no paper on antioxidant activity of the FA in testis I/R. So, the main purpose of the study was to evaluate the effects of the effect of FA on experimental testicular $\mathrm{I} / \mathrm{R}$ in rats.

\section{Methods}

This study was conducted according to the guidelines of the animal care review board of the Islamic Azad University, Faculty of Veterinary Medicine, adhering to the guide for care and use of laboratory animals; the study was approved by the ethics committee.

Sixty healthy adult male Wistar rats, (weight 250-300 g) were purchased from the Pasteur Institute. Animals kept under constant room temperature of $20 \pm 1^{\circ} \mathrm{C}$, relative humidity of $42 \pm 1 \%$, on a 12 -hour light/ dark cycle. All animals had free access to commercial food and filtered tap water.

\section{Experimental groups}

Rats randomly divided into 6 experimental groups $(n=10)$. The control group: animals received physiologic saline orally for 7 days via oral gavage ${ }^{9}$. The sham-operated group received physiologic saline orally for 7 days via oral gavage then exposed to midline laparotomy without clamping the IR. The I/R group: rats received oral gavage of the saline for 7 days and then subjected to $1 \mathrm{~h} \mathrm{I} \mathrm{/24h} \mathrm{R}$ period. Group FA $(2 \mathrm{mg} / \mathrm{kg}+\mathrm{IR})$ : rats received oral gavage of the FA $(2 \mathrm{mg} / \mathrm{kg})$ for 7 days and then subjected to $1 \mathrm{~h} \mathrm{l} / 24 \mathrm{~h}^{9}$. Group FA ( $5 \mathrm{mg} /$ $\mathrm{kg}+\mathrm{IR})$ : animals received FA $(5 \mathrm{mg} / \mathrm{kg})$ for 7 days via oral gavage, then subjected to $1 \mathrm{~h} \mathrm{I} / 24$ h. Group 10mg/kg FA + IR: animals received 
oral gavage of the FA $(10 \mathrm{mg} / \mathrm{kg})$ for 7 days via oral gavage, then subjected to $1 \mathrm{~h} \mathrm{I} / 24 \mathrm{~h}^{9}$. The doses for FA selected based on the pilot study (un-published data) and previous report ${ }^{11,12}$.

\section{Drugs and detection kits}

Folic acid was obtained from Sigma Co. (Sigma, USA). Assay kits for MDA, SOD and GPx were purchased from the Randox (Randox Laboratories Ltd., Crumlin, Antrim, United Kingdom). The dose of FA was obtained from previous studies and our pilot studies ${ }^{11,12}$.

\section{Experimental protocol}

All surgical procedures were performed under anesthesia by intraperitoneal injection of ketamine hydrochloride $(60 \mathrm{mg} / \mathrm{kg})$ and xylazine hydrochloride $(10 \mathrm{mg} / \mathrm{kg})$ then experimental testicular IR was created ${ }^{13}$. The upper left abdominal quadrant was approached through a midline laparotomy incision. During the surgical procedures, the body temperature was maintained with a heating pad. The testicular artery and vein of the left testis were occluded with a vascular clamp for $1 \mathrm{~h}$, after this process the clamp was removed and the organ was allowed to reperfusion $24 \mathrm{~h}^{13}$. At the end of the study, rats were euthanized with an overdose injection of pentobarbital $(300 \mathrm{mg} /$ $\mathrm{kg}$, i.p.), peritoneum opened and left testis was removed for further investigations. The testicle was divided into two by a sagittal section and one half was fixed in Bouin's solution. The second half of the testicle tissue was stored at $-80^{\circ} \mathrm{C}$ for the biochemical analysis. Animal handling and experimental procedures were performed according to the Guide for the Care and Use of Laboratory Animals by the US National Institutes of Health (NIH Publication No. 85-23, revised 1996) and the current laws of the Iranian government. All experimental procedures were carried in accordance with the Guide for the Care and Use of Laboratory
Animals to Investigate Experimental Pain in Animals.

\section{Tissue processing}

The tissue was fixed in Bouin's solution (7.5 mL saturated picric acid, $2.65 \mathrm{~mL}$ glacial acetic acid, and $2.5 \mathrm{~mL} 7 \%$ formaldehyde), post-fixed in $70 \%$ alcohol, and embedded in paraffin blocks. A tissue section $(5 \mu \mathrm{m})$ were obtained, deparaffinized, and stained with hematoxylineeosin. The testicular tissue was evaluated in random order with standard light microscopy by an observer who was unaware as to which group the rat had belonged ${ }^{14}$. Then, testis tissue samples from the experimental rats were fixed at BOUIN's solution for complete fixation and processed for paraffin sectioning. A tissue section about $5 \mu \mathrm{m}$ thickness were taken and stained with hematoxylin and eosin $[\mathrm{H} \&$ $E]$. The testis sections were graded numerically to assess the degree of histological changes associated with seminiferous tubule injury as previously described by Johnsen as bellow ${ }^{15}$ :

- 10: complete spermatogenesis and perfect tubules

- 9: many spermatozoa present but disorganized spermatogenesis

- 8: only a few spermatozoa present

- 7: no spermatozoa but many spermatids present;

- 6: only a few spermatids present

- 5: no spermatozoa or spermatids present but many spermatocytes present

- 4: only a few spermatocytes present

- 3: only spermatogonia present

- 2: no germ cells present

- 1: neither germ cells nor Sertoli cells present

\section{Spermatozoa characteristics}

At the end of the study, semen samples were collected from the Cauda epididymis carefully separated from the testis and placed 
in a Petri dish containing Ham's F10. Epididymal caudal was minced with scissors to release sperm and then was placed in the incubator for $15 \mathrm{~min}^{14}$. Approximately, $10 \mu \mathrm{L}$ of the diluted sperm suspension was transferred to each counting chamber of the hemocytometer and allowed to stand for $5 \mathrm{~min}$. The cells which settled during this time were counted by a light microscope at $\times 200$ magnification ${ }^{17}$.

\section{Antioxidant activity}

The tissue MDA level was determined by a method based on the reaction with thiobarbituric acid $(T B A)^{18}$. In the TBA test reaction, MDA or MDA-like substances and TBA react with the production of a pink pigment with a maximum absorption at $532 \mathrm{~nm}^{19}$. The SOD activity was expressed as $\mathrm{nmol} / \mathrm{g}$ tissue. The GPx catalyses the oxidation of glutathione and in the presence of glutathione reductase and NADPH, oxide glutathione converts to the reduced form by changes in oxidation of NADPH to NADP ${ }^{+}$. The GPx level was measured in absorbance of $340 \mathrm{~nm}^{20}$. The GPx activity was expressed as $\mathrm{U} / \mathrm{mg}$ tissue. Tissue SOD activity was measured according to the method of Paoletti and Mocali ${ }^{21}$. In brief, the superoxide anions were generated from manganese (II) chloride and mercaptoethanol in the presence of acidethylenediaminetetraacetic acid. The SOD level was determined on the basis of its ability to inhibit nicotinamide adenine dinucleotide oxidation in reaction mixture after the addition of tissue homogenate. Nicotinamide adenine dinucleotide oxidation was measured was measured at $340 \mathrm{~nm}$. The SOD activity was expressed as $\mathrm{U} / \mathrm{mg}$ tissue.

\section{Statistical analysis}

Data were prepared in excel, the parametric data analyzed with one-way analysis of variance (ANOVA) using SPSS
16.0 for Windows (SPSS, Inc., Chicago, IL, USA). Data were expressed as mean values \pm standard error of mean (SEM). Where heterogenecity occurred, the groups were separated using Duncan Multiple Range Test. The KruskaleWallis test was used to compare group medians for histopathological scores. $\mathrm{P}<0.05$ was considered to denote significant differences between groups.

\section{- Results}

The effect of different levels FA on Score for assessing in testis and sperm mortality in experimental testicular I/R-induced rat is presented in Table 1. As seen in Figure 1, I/R group had the lowest testis damage grade compared to the other groups $(P<0.05)$. The testis damage grade was higher among the control and sham $(P>0.05)$. A dose dependent difference detected on testis damage grade in FA treated groups compared with I/R group $(P<0.05)$. No difference observed between 2 and $5 \mathrm{mg} / \mathrm{kg}$ of the FA groups ( $P>0.05)$.

Table 1 - Effect of different levels FA on Score for assessing in testis and sperm mortality in experimental testicular I/R-induced rat.

\begin{tabular}{|c|c|c|c|}
\hline Group & $\begin{array}{l}\text { Score for } \\
\text { assessing } \\
\text { in testis }\end{array}$ & $\begin{array}{l}\text { Mortality } \\
\text { (\%) }\end{array}$ & $\begin{array}{l}\text { Mobility } \\
(\%)\end{array}$ \\
\hline Control & $10^{\mathrm{a}}$ & $72^{\mathrm{a}}$ & $70^{\mathrm{a}}$ \\
\hline Sham & $3.2^{\mathrm{a}}$ & $71^{\mathrm{a}}$ & $68.5^{a}$ \\
\hline I/R & $4^{b}$ & $40^{b}$ & $39.4^{b}$ \\
\hline $\begin{array}{l}\text { FA } \\
(2 \mathrm{mg} / \mathrm{kg})\end{array}$ & $7^{c}$ & $43^{c}$ & $42.9^{c}$ \\
\hline $\begin{array}{l}\text { FA } \\
(5 \mathrm{mg} / \mathrm{kg})\end{array}$ & $8.5^{c}$ & $55^{c}$ & $55.2^{c}$ \\
\hline $\begin{array}{l}\text { FA } \\
(10 \mathrm{mg} / \mathrm{kg})\end{array}$ & $10^{d}$ & $67^{d}$ & $66.8^{d}$ \\
\hline
\end{tabular}

FA: folic acid, I/R: ischemia/reperfusion. Different letters (a-d) indicate significant differences between treatments $(P<0.05)$. 


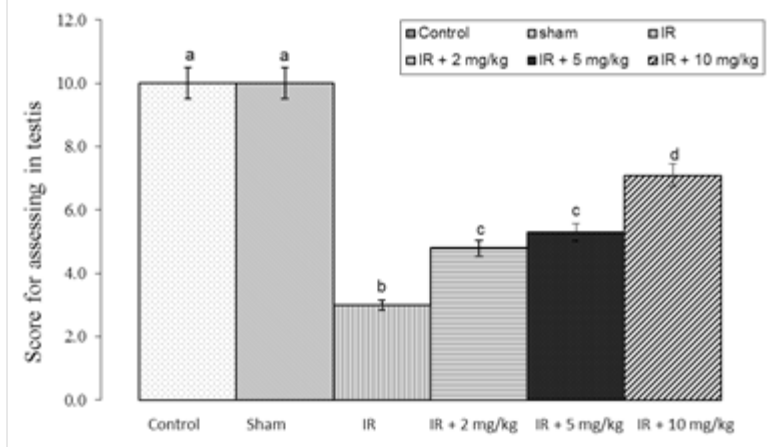

Figure 1 - Score of histological changes associated with seminiferous tubules injury in experimental $I / R$ rat. Different letters (a-d) indicate significant differences between treatments $(P<0.05)$.

As seen in Figure 2, spermatozoa mobility (\%) significantly decreased in $\mathrm{I} / \mathrm{R}$ group $(P<0.05)$. Dose dependent increase observed on spermatozoa mobility (\%) using different levels of the FA $(2,5$ and $10 \mathrm{mg} / \mathrm{kg})$ treated rat $(P<0.05)$. No difference detected among 2 and $5 \mathrm{mg} / \mathrm{kg}$ of the FA groups ( $P>0.05)$.

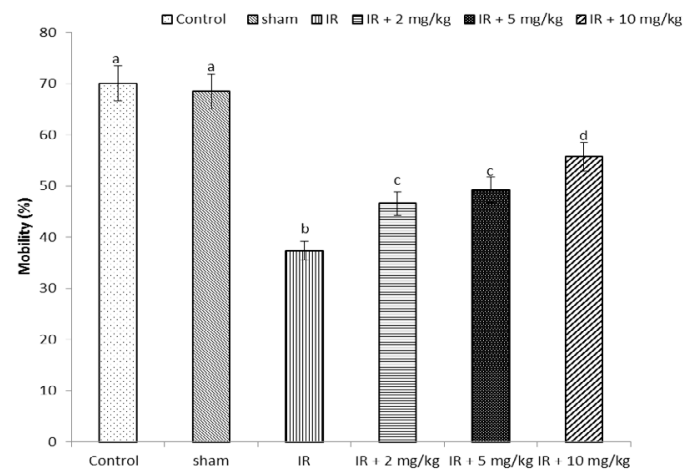

Figure 2 - Effect of different levels FA on spermatozoa mobility (\%) in experimental testicular I/R-induced rat. Different letters $(\mathbf{a}-\mathbf{d})$ indicate significant differences between treatments $(P<0.05)$. The KruskaleWallis test was used to compare group medians for histopathological scores.

According to the results, spermatozoa mortality (\%) significantly decreased in $\mathrm{l} / \mathrm{R}$ group compared to the control and sham groups $(P<0.05)$ (Figure 3$)$. Furthermore, dose dependent increase observed on spermatozoa mortality (\%) in FA $(2,5$ and $10 \mathrm{mg} / \mathrm{kg})$ treated rat $(P<0.05)$ but no difference observed between groups 2 and $5 \mathrm{mg} / \mathrm{kg}$ of the FA ( $P>0.05)$.

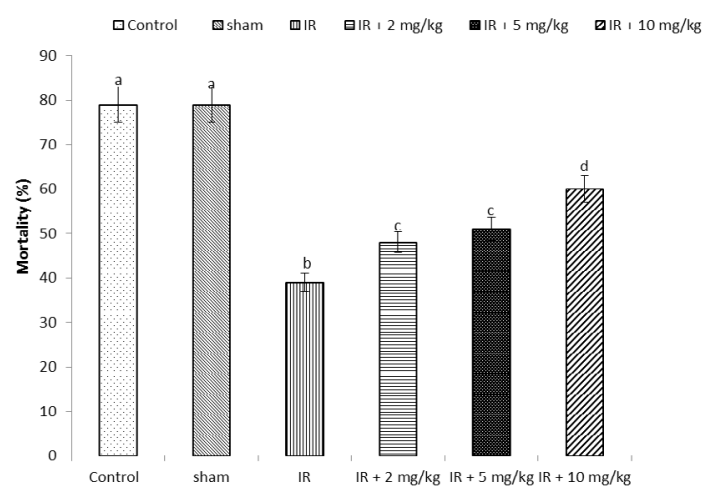

Figure 3 - Effect of different levels FA on spermatozoa mortality (\%) in experimental testicular I/R-induced rat. Different letters (a-d) indicate significant differences between treatments $(P<0.05)$. The KruskaleWallis test was used to compare group medians for histopathological scores.

Effect of different levels FA on tissue values of MDA, SOD and GPx in experimental testicular I/R-induced rat is presented in Table 2. According to the results tissue MDA levels significantly increased in $I / R$ rat $(P<0.05)$ while FA $(2,5$ and $10 \mathrm{mg} / \mathrm{kg})$ in a dose dependent manner decreased I/R-induced MDA $(P<0.05)$. Experimental I/R significantly decreased SOD activity compared to control group $(P<0.05)$. Administration of the FA $(2,5$ and $10 \mathrm{mg} / \mathrm{kg})$ significantly increased tissue SOD activity in $I / R$ rat $(P<0.05)$. Orally gavage of the different levels of the FA $(2,5$ and $10 \mathrm{mg} / \mathrm{kg})$ in a dose dependent manner increased GPx activity in $\mathrm{I} / \mathrm{R}$ rat $(\mathrm{P}<0.05)$. 
Table 2 - Effect of different levels FA on tissue values of Malondialdehyde, Superoxide dismutase and Glutathione peroxidase in experimental testicular I/R-induced rat.

\begin{tabular}{llll} 
Group & MDA (nmol/g tissue) & SOD (U/mg tissue) & GPx (U/mg tissue) \\
\hline Control & $130.26 \pm 12.32^{\mathrm{d}}$ & $3.62 \pm 0.14^{\mathrm{a}}$ & $4.11 \pm 0.09^{\mathrm{a}}$ \\
Sham & $131.37 \pm 11.42^{\mathrm{d}}$ & $3.57 \pm 0.19^{\mathrm{a}}$ & $4.12 \pm 0.10^{\mathrm{a}}$ \\
I/R & $172.37 \pm 14.20^{\mathrm{a}}$ & $2.11 \pm 0.08^{\mathrm{d}}$ & $2.09 \pm 0.08^{\mathrm{d}}$ \\
FA (2 $\mathbf{~ m g / k g ) ~}$ & $158.14 \pm 13.59^{\mathrm{b}}$ & $2.24 \pm 0.15^{\mathrm{c}}$ & $2.91 \pm 0.09^{\mathrm{c}}$ \\
FA (5 mg/kg) & $154.42 \pm 12.07^{\mathrm{b}}$ & $2.25 \pm 0.11^{\mathrm{c}}$ & $3.10 \pm 0.12^{\mathrm{c}}$ \\
FA (10 $\mathbf{~ m g / k g ) ~}$ & $141.10 \pm 11.23^{\mathrm{c}}$ & $3.22 \pm 0.21^{\mathrm{b}}$ & $3.09 \pm 0.09^{\mathrm{b}}$ \\
\hline
\end{tabular}

FA: folic acid, MDA: malondialdehyde, SOD: superoxide dismutase, GPx: glutathione peroxidase, I/R: ischemia/reperfusion. Different letters $(a-d)$ indicate significant differences between treatments $(P<0.05)$.

The effect of FA on testis histopathology is shown in Figures 4 to 9. According to the results, testis section of control (Figure 4)

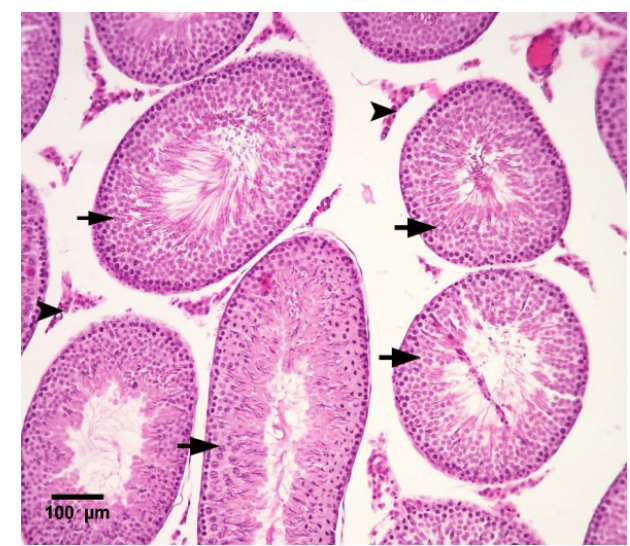

and sham (Figure 5) rats had shown normal seminiferous tubules and spermatogenesis with spermatocytes, Sertoli and spermatozoa.

Figure 4 - Testis section of control rats showing normal seminiferous tubules (arrow) and interstitial cells (arrow head) between tubules (left), testis section of control rats showing normal seminiferous tubules with spermatogonia (black arrow), spermatocyte (black arrow head) and many spermatozoa (white arrow) (right) (Hematoxylin and Eosin - H\&E).
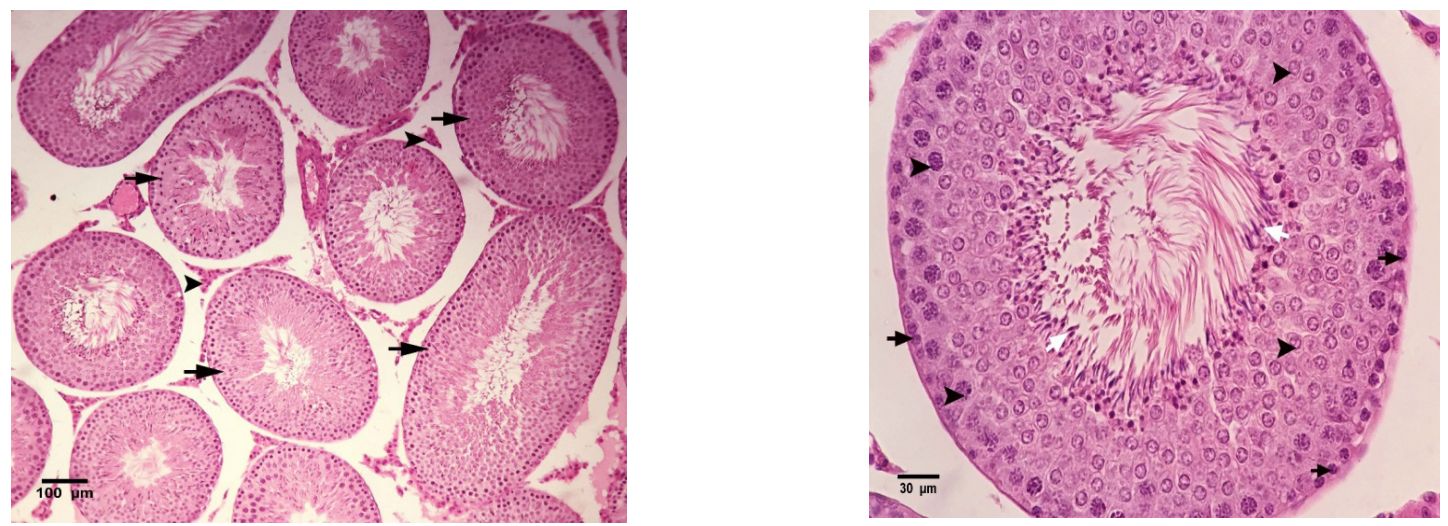

Figure 5 - Testis section of sham rats showing normal seminiferous tubules (arrow) and interstitial cells (arrow head) between tubules (left), testis section of control rats showing normal seminiferous tubules with spermatogonia (black arrow), spermatocyte (black arrow head) and many spermatozoa (white arrow) (right) (H\&E). 
Based on the Figure 6, seminiferous tubules degenerated and loss of spermatogenesis with few spermatocytes was observed in degenerated testis tubules in $\mathrm{I} / \mathrm{R}$ rat.

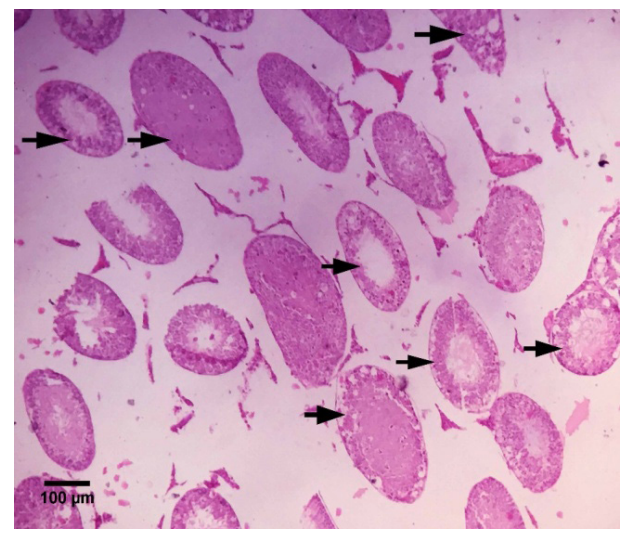

Based on the results of Figure 7, seminiferous tubules degenerated and loss of spermatogenesis with few spermatocytes was observed in degenerated in orally administration of the FA $(2 \mathrm{mg} / \mathrm{kg})$ followed by $\mathrm{I} / \mathrm{R}$ rats.

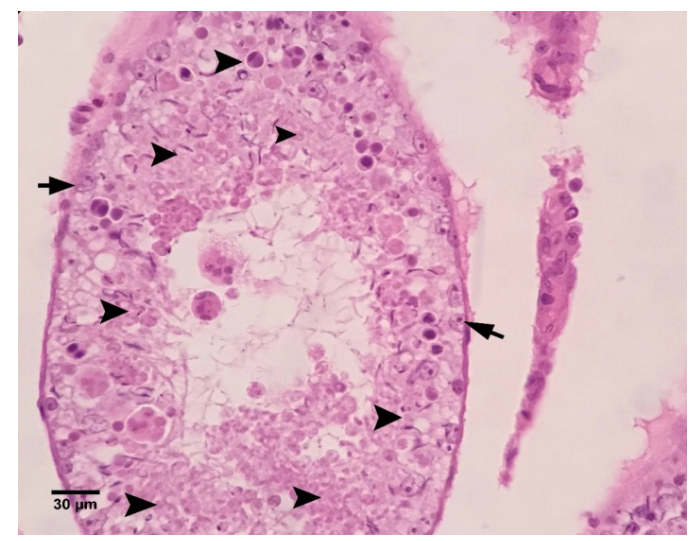

Figure 6 - Testis section of I/R rats showing degenerated seminiferous tubules (arrow) and loss of spermatogenesis (H\&E) (left) and degenerated seminiferous tubules (arrow) with few spermatocyte (arrowhead) in degenerated tubules (right) (H\&E).
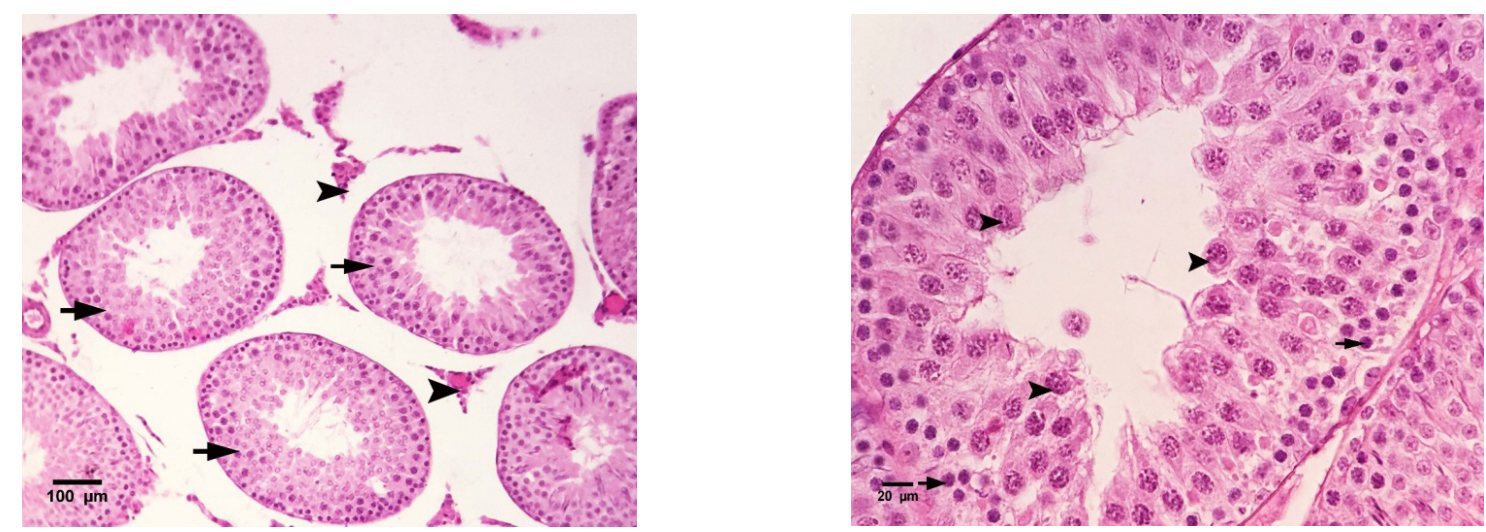

Figure 7 - Testis section of 7 days orally administration of the FA $(2 \mathrm{mg} / \mathrm{kg})$ followed by $\mathrm{I} / \mathrm{R}$ rats showing seminiferous tubules (arrow) with few spermatocyte and interstitial cells (arrow head) between tubules (left) and seminiferous tubules with few spermatocyte (arrow head) and spermatogonia (arrow) (right). H\&E.

As seen in Figure 8, orally administration of the FA (5 $\mathrm{mg} / \mathrm{kg})$ improved testis characteristics with few normal seminiferous tubules and spermatocyte in seminiferous tubules in experimental I/R-induced rat.
Also, orally administration of the FA (10 $\mathrm{mg} / \mathrm{kg}$ ) improved testis characteristics with few normal seminiferous tubules and spermatocyte in seminiferous tubules in experimental I/Rinduced rat (Figure 9). 

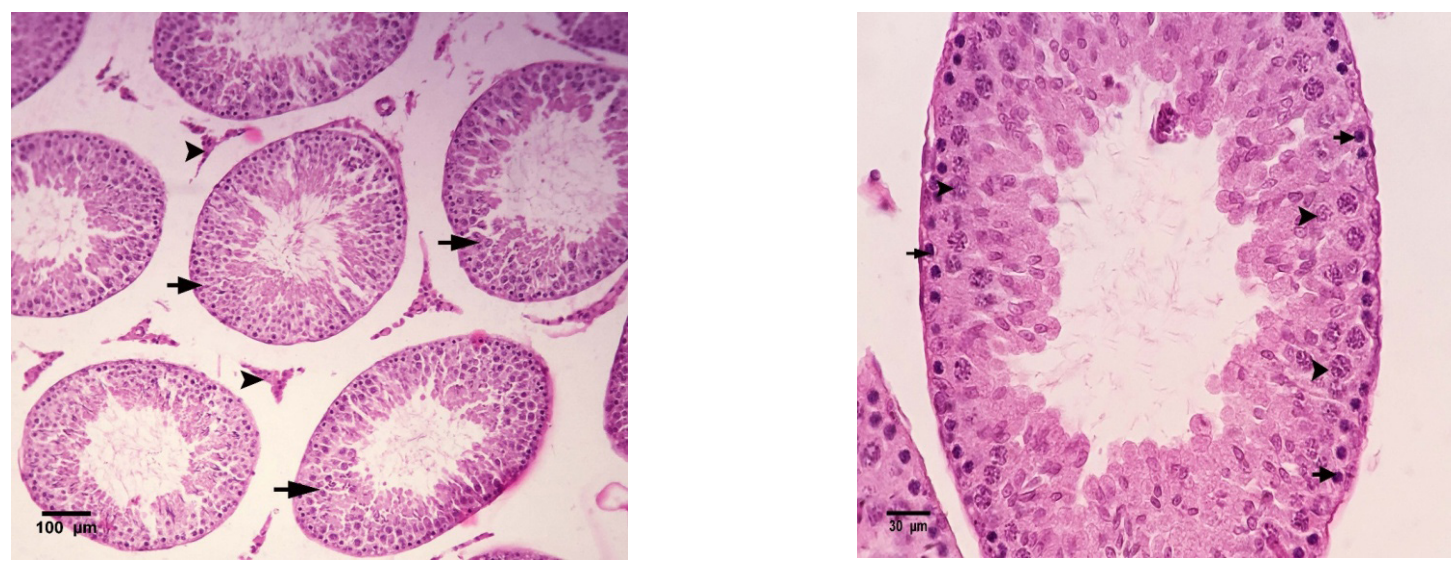

Figure 8 - Testis section of 7 days orally administration of the FA $(5 \mathrm{mg} / \mathrm{kg})$ followed by $\mathrm{l} / \mathrm{R}$ rats showing seminiferous tubules (arrow) with few spermatocyte and interstitial cells (arrow head) between tubules (left) and seminiferous tubules with $f$ spermatocyte (arrow head) and spermatogonia (arrow) and few spermatid (right). H\&E.
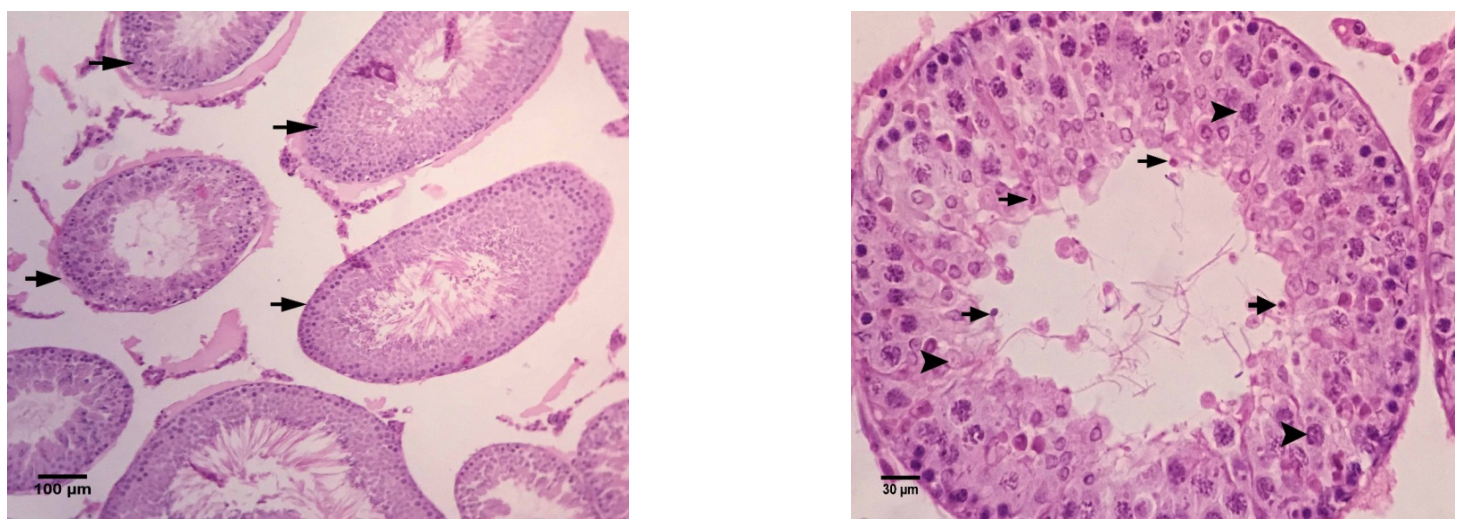

Figure 9 - Testis section of 7 days orally administration of the FA $(10 \mathrm{mg} / \mathrm{kg})$ followed by $1 / \mathrm{R}$ rats showing many normal seminiferous tubules (arrow) (left) and many spermatocyte (arrow) in seminiferous tubules (right). H\&E.

\section{- Discussion}

To the best of our knowledge, there are limited studies describing the role of FA on spermatozoa characteristics in experimental I/R rat. This study was conducted for the first time to investigate the effect of FA on testis histopathology and semen MDA, SOD and GPx in experimental I/R rat. The most pathogenetic mechanism of $I / R$ injury is the over generation of $R^{2}{ }^{22}$. During testicular $I / R$, the ROS production increased injury on ischemic tissue via oxidation of cell membrane lipids, proteins and DNA ${ }^{23}$. The ROS have destructive effects on various cellular components in the organism ${ }^{24}$. This may lead to molecular or genetic changes and pathologic features such as infertility ${ }^{7}$. As observed in the current study, tissue MDA levels significantly increased in I/R rat while FA (2, 5 and $10 \mathrm{mg} / \mathrm{kg}$ ) in a dose dependent manner decreased I/R-induced MDA. Experimental I/R significantly decreased SOD and GPx activity. Administration of the FA $(2,5$ and $10 \mathrm{mg} / \mathrm{kg})$ significantly increased tissue SOD and GPX 
activity in $\mathrm{I} / \mathrm{R}$ rat.

MDA is the end product of lipid peroxidation and its elevated level is an indicator for free radical formation in postischemic tissue ${ }^{25}$. Additionally, SOD and GPx are major enzymes that scavenge harmful ROS in male reproductive system ${ }^{26}$. Based on the reports, I/R increased MDA and decrease SOD as well as GPx which leads to formation of inflammatory mediators ${ }^{15}$. Spermatozoa membranes contain polyunsaturated fatty acids which are vulnerable to the ROS ${ }^{24}$. In the testis, MDA levels elevates in case of the lipid peroxidation which leads to infertility ${ }^{27}$. As observed in this study, spermatozoa mobility and mortality (\%) significantly decreased in I/R group (Figures 2-3). Also, seminiferous tubules degenerated and loss of spermatogenesis with few spermatocytes was observed in degenerated testis tubules in I/R rat (Figure 7).

As observed, FA $(2,5$ and $10 \mathrm{mg} / \mathrm{kg})$ in a dose dependent manner decreased I/R-induced MDA. The FA $(2,5$ and $10 \mathrm{mg} / \mathrm{kg})$ significantly increased tissue SOD and GPx activity in I/R rat (Table 1). Supplementation of the FA decreases the risk of heart and limb defects ${ }^{26}$ and urinary tract anomalies ${ }^{29-30}$. The $\mathrm{I} / \mathrm{R}$ injury in testis resulted in decrease in spermatogenesis ${ }^{31}$. The anti-inflammatory potentials of FA against $I / R$ in rat testes was reported. FA has positive effect in the normal spermatogenesis, maturation and DNA metabolism, synthesis and transcription ${ }^{32}$. Several researches confirm the repairing and maintenance role of FA during oxidative stress ${ }^{32}$. However, Raigani reported FA supplementation did not ameliorate sperm quality in infertile men ${ }^{28}$.

The FA successfully alleviated the SOD, GPx depletion and MDA elevation ${ }^{29}$. In this study, dose dependent increase observed on spermatozoa mobility, mortality (\%) using different levels of the FA $(2,5$ and $10 \mathrm{mg} / \mathrm{kg})$ treated rat (Figures 2-3). Orally administration of the FA ( 5 and $10 \mathrm{mg} / \mathrm{kg}$ ) improved testis characteristics with few normal seminiferous tubules and spermatocyte in seminiferous tubules in experimental I/R-induced rat (Figures 9-10). In this regard, $74 \%$ increase in the sperm count in the men reported after administration of the FA. Also, FA ( $3 \mathrm{mg} /$ day for 3 months) improved spermatozoa number and motility in infertile men ${ }^{29}$. FA could protect cells against damage caused by lead ${ }^{32}$. Therefore, FA supplementation affected positively spermatogenesis ${ }^{32}$. Orally administration of the FA $(2 \mathrm{mg} / \mathrm{kg}$ ) for 7 days decreased MDA concentration in indomethacin-induced gastropathy in rats ${ }^{11}$. In a similar study Şener et $a l .{ }^{33}$ reported administration of the apocynin (20 and $50 \mathrm{mg} / \mathrm{kg}$ ) in 4 hours torsion and then reperfusion for 4 hours, normalized elevated oxidative enzyme levels in Rat which our results was similar to their findings. Also, in a study on effect of intraperitoneal injection of the Nifedipine $(100 \mathrm{mg} / \mathrm{kg})$ on testicular torsion-detorsion injury in rats, Mestrovic et $a .^{34}$ reported Nifedipine significantly decreased MDA and increased SOD and GPX levels which our results was in agreement to this report. On protective effect of Urapidil on testicular torsion Meštrovic' et al. ${ }^{35}$ reported intraperitoneal injection of the $10 \mathrm{ml} / \mathrm{kg}$ of the Urapidil $30 \mathrm{~min}$ before detorsion significantly significantly decreased MDA and increased SOD and GPx levels on testicular torsion-detorsion injury in rats. Also, Ozbek et al. ${ }^{36}$ revealed intraperitoneal injection of the Apocynin (20 $\mathrm{mg} / \mathrm{kg}$ ) significantly increased SOD, GPx and CAT and decreased MDA levels in $4 \mathrm{~h}$ torsion followed by $1 \mathrm{~h}$ detorsion rats.

\section{- Conclusions}

Folic acid prevents the progression of I/R-induced infertility by decrease elevated MDA levels in rat. Also, FA act as antioxidant 
and free radical scavenging activity through increase SOD and GPX levels in I/R-induced rat. Our results indicate FA could be used as an important therapeutic intervention in testicular $I / R$ injury. The new findings of the current study can use as base information and further researches needed to determine effect of FA in human clinical trial.

\section{References}

1. Yuluğ $E$, Türedi $S$, Alver $A$, Türedi $S$, Kahraman C. Effects of resveratrol on methotrexate-induced testicular damage in rats. Sci World J. 2013;2013:489659. doi: 10.1155/2013/489659.

2. Pogorelić Z, Mrklić I, Jurić I, Biočić M, Furlan $D$. Testicular torsion in the inguinal canal in children. J Pediatr Urol. 2013;9(6 Pt A):7937. doi: 10.1016/j.jpurol.2012.10.013.

3. Pogorelić Z, Mustapić K, Jukić M, Todorić J, Mrklić I, Mešštrović J, Jurić I, Furlan D. Management of acute scrotum in children: a 25-year single center experience on 558 pediatric patients. Can J Urol. 2016;23(6):8594-601. PMID: 27995859.

4. Asghari A, Akbari G, Beigi A.M, Mortazavi P. Tramadol reduces testicular damage of ischemia-reperfusion rats. Anim Reprod. 2016;13(4):811-9. doi: 10.21451/19843143-AR823.

5. Parlaktas BS, Atilgan D, Gencten Y, Akbas A, Markoc F, Erdemir F, Ozyurt H, Uluocak $N$. The effects of carvedilol on ischemiareperfusion injury in the rat testis. Int Braz J Urol. 2014;40:109-1. doi: 10.1590/S16775538.IBJU.2014.01.16.

6. Ozbal S, Ergur BU, Erbil G, Tekmen I, Bagriyanık A, Cavdar Z. The effects of $\alpha$-lipoic acid against testicular ischemia-reperfusion injury in rats. Sci World J. 2012;2012:489248. doi: $10.1100 / 2012 / 489248$.

7. Nematollahi-Mahani SN, Azizollahi GH, Baneshi MR, Safari Z, Azizollahi S. Effect of folic acid and zinc sulphate on endocrine parameters and seminal antioxidant level after varicocelectomy. Andrologia. 2014 Apr;46(3):240-5. doi: 10.1111/and.12067.

8. Elshaari FA, Elfagih RI, Sheriff DS, Barassi IF. Oxidative and antioxidative defense system in testicular torsion/detorsion. Indian J Urol. 2011;27:479-84. doi: 10.4103/09701591.91436.

9. Asghari A, Akbari G, Meghdadi A, Mortazavi P. Effects of melatonin and metformin coadministration on testicular ischemia/ reperfusion injury in rats. J Pediatr Urol. 2016 Dec;12(6):410.e1-410.e7. doi: 10.1016/j. jpurol.2016.06.017.

10.Morjan S, Al Laham S, Atieh R. Gastroprotective efficacy of folic acid and omeprazole in indomethacin-induced gastropathy in rats. Int J Pharmacogn Phytochem Res. 2013;5(2):13-119.

11.Ajeigbe KO, Olaleye SB, Oladejo EO, Olayanju AO. Effect of folic acid supplementation on oxidative gastric mucosa damage and acid secretory response in the rat. Indian J Pharmacol. 2011;43:578-81. doi: 10.4103/0253-7613.84976.

12. Mohammadian Z, Eidi A, Mortazavi P, Tavangar SM, Asghari A. Effects of folic acid on dyslipidemia and serum homocysteine in a rat model of cholestasis and hepatic fibrosis. Pol J Pathol. 2015;66(1):49-56. PMID: 26017880.

13.Koksal M, Oğuz E, Baba F, Eren Ali M, Ciftci $H$, Demir ME, Kurcer Z, Take G, Aral F, Ocak AR, Aksoy N, Ulas T. Effects of melatonin on testis histology, oxidative stress and spermatogenesis after experimental testis ischemia-reperfusion in rats. Eur Review Med Pharmacol Sci. 2012;16:582-8. PMID: 22774397.

14.Dal Lago A, Lucke SA. Method of fixing rat testis for light and electron microscopy. Stain Techn. 1973;48(6):289-95. doi: $10.3109 / 10520297309116644$.

15.Johnsen S. Testicular biopsy score count-a method for registration of spermatogenesis in human testes: normal values and results in 335 hypogonadal males. Hormone Res Paediatrics. 1970;1(1):2-25. PMID: 5527187.

16.Padmanabhan S, Tripathi DN, Vikram A, Ramarao P, Jena GB. Cytotoxic and genotoxic effects of methotrexate in germ cells of male Swiss mice. Mutation Res Genetic Toxicol Environ Mutagenesis. 2008;655(1):59-67. doi: 10.1016/j.mrgentox.2008.07.003.

17. World Health O. WHO laboratory manual for the examination of human semen 
and sperm-cervical mucus interaction. Cambridge: University Press; 1999.

18. Wasowicz W, Ne`ve J, Peretz A. Optimized steps in fluorometric determination of thiobarbituric acid reactive substances in serum: importance of extraction $\mathrm{pH}$ and influence of sample preservation and storage. Clin Chem. 1993;39:e2522-6. PMID: 8252725.

19.Placer ZA, Cushman LL, Johnson BC. Estimation of product of lipid peroxidation (malondialdehyde) in bio-chemical systems. Anal Biochem 1966;16:359-64. PMID: 6007581.

20.Paglia DE, Valentine VN. Studies on the quantitative and qualitative characterization of erythrocyte glutathione peroxidase. J Lab Clin Med. 1967;70:158-69. PMID: 6066618.

21.Paoletti F, Mocali A. Determination of superoxide dismutase activity by purely chemical system based on $\mathrm{NAD}(\mathrm{P}) \mathrm{H}$ oxidation. Methods Enzymol. 1990;186:e209-20. PMID: 2233293.

22.Altunoluk B, Söylemez H, Bakan V, Ciralik H, Tolun FI J. Protective effects of zofenopril on testicular torsion and detorsion injury in rats. Urology. 2011;8:313-9. PMID: 22090052.

23.Wang ZS, Liu XH, Wang M, Jiang GJ, Qiu T, Chen ZY, Wang L. Metformin attenuated the inflammation after renal ischemia/ reperfusion and suppressed apoptosis of renal tubular epithelial cell in rats. Acta Cir Bras. 2015;30:e617-23. doi: 10.1590/S0102865020150090000006.

24.Asghari A, Akbari G, Meghdadi A, Mortazavi P. Protective effect of metformin on testicular ischemia/reperfusion injury in rats. Acta Cir Bras. 2016;31(6):411-6. doi: 10.1590/S0102-865020150090000006.

25.Takhtfooladi MA, Jahanshahi A, Sotoudeh A, Daneshi MH, Khansari M, Takhtfooladi HA. The antioxidant role of $\mathrm{N}$-acetylcysteine on the testicular remote injury after skeletal muscle ischemia and reperfusion in rats. Pol J Pathol. 2013;64(3):204-9. PMID: 24166607.

26.Takhtfooladi MA, Moayer F, Takhtfooladi $H A$. Beneficial effect of pentoxifylline into the testis of rats in an experimental model of unilateral hindlimb ischemia/reperfusion injury. Int Braz J Urol. 2015;41(3):576-83. PMID: 26200554.
27. Hadwan $\mathrm{MH}$, Almashhedy LA, Alsalman ARS. Study of the effects of oral zinc supplementation on peroxynitrite levels, arginase activity and NO synthase activity in seminal plasma of Iraqi asthenospermic patients. Reprod Biol Endocrinol. 2014;12:1. doi: 10.1186/1477-7827-12-1.

28. Raigani M, Yaghmaei B, AmirjanntiN, Lakpour W, Akhondi M.M, Zeraati $\mathrm{H}$, Hajihosseinal M., Sadeghi MR. The micronutrient supplements, Zinc sulphate and folic acid did not ameliorate sperm functional parameters in oligoasthenoteratozoospermic men. Andrologia. 2014;46(9):956-62. doi: 10.1111/and.12180.

29. Majumdar S, Maiti A, Karmakar S, Das AS, Mukherjee S, Das D, Mitra C. Antiapoptotic efficacy of folic acid and vitamin B12 against arsenic-induced toxicity. Environ Toxicol. 2010;27:351-63. doi: 10.1002/tox.20648.

30.Alférez MJ, Rivas E, Díaz-Castro J, Hijano $S$, Nestares T, Moreno $M$, Campos MS, Serrano-Reina JA, López-Aliaga I. Folic acid supplemented goatmilk has beneficial effects on hepatic physiology, haematological status and antioxidant defence during chronic Fe repletion. J Dairy Res. 2015;82:86-94. doi: $10.1017 /$ S0022029914000624.

31. Murphy LE, Mills JL, Molloy AM, Qian C, Carter TC, Strevens $H$, Wide-Swensson D, Giwercman A, Levine RJ. Folate and vitamin B12 in idiopathic male infertility. Asian J Androl. 2011;13:856-61. doi: 10.1038/ aja.2011.96.

32.Williams PJ, Bulmer JN, Innes BA, Broughton Pipkin F. Possible roles for folic acid in the regulation of trophoblast invasion and placental development in normal early human pregnancy. Biol Reprod. 2011;84:1148-53. doi: 10.1095/ biolreprod.110.088351.

33.Şener TE, Yüksel M, Özyılmaz-Yay N, Ercan F, Akbal C, Şimşek F, Şener G. Apocynin attenuates testicular ischemia-reperfusion injury in rats. J Pediatr Surg. 2015;50(8):13827. doi: 10.1016/j.jpedsurg.2014.11.033.

34.Mestrovic J, Drmic-Hofman I, Pogorelic Z, Vilovic K, Supe-Domic D, Seselja-Perisin A, Capkun V. Beneficial effect of Nifedipine on testicular torsion-detorsion injury in rats. Urology. 2014;84:1194-8. doi: 10.1016/j. urology.2014.07.022. 
35.Meštrovic' J, Pogorelic' Z, Drmic'-Hofman I, Vilovic' K, Todoric'D, Popovic M. Protective effect of urapidil on testicular torsiondetorsion injury in rats. Surg Today. 2017;47(3):393-8. doi: 10.1007/s00595016-1388-3.
36.Ozbek O, Altintas R, Polat A, Vardi N, Parlakpinar H, Sagir M, Duran ZR, Yildiz A. The Protective effect of Apocynin on testicular ischemia-reperfusion injury, J Urol. 2014;193(4):1417-22. doi: 10.1016/j. juro.2014.11.086.

\section{Correspondence:}

Prof. Ahmad Asghari

Department of Surgery, Science and Research

Branch

Islamic Azad University, Tehran Iran

Phone: +9809144147924

dr.ahmad.asghari@gmail.com

Received: May 13, 2017

Review: July 15, 2017

Accepted: Aug 18, 2017
Conflict of interest: none

Financial source: none
${ }^{1}$ Research performed at Department of Veterinary Medicine, Science and Research Branch, Islamic Azad University, Tehran, Iran. 